\title{
İZNİK ROMA TIYYAROSU BİZANS TOPLUMUNDA DİŞ SAĞLIĞI
}

Aygün Ekin MERIÇ*

Ruken Zeynep KÖSE*

Atıf/O: Meriç, Aygün Ekin, Köse, Ruken Zeynep (2018). İznik Roma Tiyatrosu Bizans Toplumunda Diş Sağlığı, Hitit Üniversitesi Sosyal Bilimler Enstitüsü Dergisi, ANARSAN Sempozyumu Özel Sayısı, Ekim 2018, Cilt 11 Sayı 2 , ss. 893-901

Özet: İznik Roma Tiyatrosunda 2012-2015 yillan arasinda yapılan kazı çalışmalarında Geç Bizans" dönemine ait 30 bireyin diş kalıntılar üzerine çalışıldl. Geçmiş toplulukların kültürel ve biyolojik çeşitliliğini oluşturan iskelet ve diş kalıntılar antropolojik çalışmalar için önemli veriler sunmaktadır. Diş minesi iskelet kalıntısının en sağlam kısmını oluşturduğu için kötü şartlar altında kalsa bile incelenebilmektedir. Dişler toplumun; beslenme ve yaşam şekilleri, sosyoekonomik durumu gibi birçok konuda aydınlatıc bilgiler sunar. Aynca dis kalıntılar üzerinden toplumlar arası yakınlık-uzaklık ve varyasyonlar da saptanabilmektedir. Bu çalışmada bireylerin cinsiyet ve yaşı belirlenerek toplamda 128 diş kalıntısı; diş çürügü, apse, aşınma, diş taşı, hypoplasia ve antemortem bakımından incelenmiştir. Inceleme sonucunda elde ettiğimiz verilere göre o dönemde yaşayan insanların diş sağliğına önem vermediğ görülmüştür.

Anahtar Kelimeler: İznik Roma Tiyatrosu, Antropoloji, Diş sağlı̆̆

Makale Geliș Tarihi:24.09.2018 / Makale Kabul Tarihi: 24.10.2018

Bu makale Turnitin programinda kontrol edildi. This article was checked by Turnitin.

Bu makale ANARSAN sempozyumunda sunulmuş aynı başlıklı bildirinin tam metnidir.

*Doç., Dr., Dokuz Eylül Üniversitesi, Arkeoloji Bölümü, ayqun.ekin@deu.edu.tr

** Antropololog, İznik Roma Tiyatro Kazı Ekibi, rknzynpp@gmail.com 


\section{The Dental Health In The Community Byzantine In Iznik Roman Theater}

Citation/@: Meriç, Aygün Ekin, Köse, Ruken Zeynep (2018). The Dental Health In The Community Byzantine In İnik Roman Theater, Hitit University Journal of Social Sciences Institute, Symposium of AAHA, Special Issue, Year 11 Volume 2 October 2018, ss. 893-901

Abstract: In the excavations carried out at the Iznik Roman Theater between the years 2012 and 2015, 30 tooth residues of the human beings belongs to "Late Byzantine" period were studied. Skeletal and dental remains, which contain the cultural and biological diversity of past communities, provide important data for the anthropological studies. Because the strongest part of skeletal remains was the dental mine, so that it can be examined even if it remains in bad conditions. Based on the study on the teeth; the habit of nutrition, lifestyle, and their socioeconomic status reveal many enlightening knowledge. In additon, due to the study on the teeth, the imntercommunial kinship and the teeth variations of the human beings who lived in the past can also be determined. In this paper 128 teeth was investigated in point of tooth decay, apse, corrosion, tartar, hypoplasia, antemortem by determining gender and age. According to the findings obtained from investigation, it has been determined that the human beings did not given a very good care of their dental health.

Keywords: Iznik Roman Theater, Anthropology, Dental health

\section{GİRIŞ}

Anadolu geçmişten günümüze birçok medeniyete, uygarlığa ve kültüre ev sahipliği yapmıştır. Bu kapsamda antropolojik ve arkeolojik kazılar için zengin ve değerli bir veri kaynağına sahiptir. Kazılarda ele geçirilen iskelet kalıntıları geçmişte yaşayan insanların, yaşam şekilleri, demografik yapısı, sosyo-ekonomik durumu, sağlık ve beslenme örüntüleri gibi birçok konuda önemli bilgileri aydınlatmaktadır. Ayrıca kültürel ve biyolojik çeşitlilik açısından iskelet kalıntıları antropolojik çalışmalar için önemli veriler sunmaktadır. İskelet kalıntısı; çevre, toprak yapısı gibi kötü şartlar altında kaldığında korunamayabilmektedir. (Sözer, Erol, 2017) Dişler, iskeletin sağlam ve dayanaklı kısmını oluşturmaktadır. Kazı çalışmaları sırasında ele geçirilen iskelet kalıntıları olumsuz koşullara rağmen, diş en fazla bulunan materyaldir.(Emiroğlu, Aydın, 2003:228) Diş dokusu, iskeletteki diğer 
kemiklere oranla yapı bakımından sert ve sağlam olması antropolojik çalışmalar açısından avantajlıdır.

\section{MATERYAL VE METOT}

Bursa ilinin $86 \mathrm{~km}$ kuzeydoğusundaki İznik ilçesi, Selçuk mahallesi Saraybahçe mevkiinde yer alan Roma Açıkhava Tiyatrosu ilk kazılar 1980 yılında Doç. Dr. Bedri Yalman'ın başkanlığında 2006 yılına kadar belirli periyotlarla devam etmiştir. Daha sonra ara verilen kazı çalışmalarına 2011 yılında İznik Müze Müdürlüğünce tekrar başlamış ve 2014 yılına kadar çalışmalarını sürdürmüştür. 2015 yılında Uludağ Üniversitesi Sanat Tarihi bölümünden Yrd. Doç. Dr. Ayşin Özügül müze başkanlığında bilimsel danışmanlık yapmıştır. 2016 yılında ise Dokuz Eylül Üniversitesi Arkeoloji Bölümünden Doç. Dr. Aygün Ekin Meriç başkanlığında kazı çalışmalarına başlamıştır ve hala devam etmektedir. (Meriç, 2017:8) Ayrıca 1980-1996 yılları arası İznik Roma Tiyatrosunda çıkan iskelet kalıntıları Prof. Dr. Metin Özbek ve Prof. Dr. Yılmaz Selim Erdal tarafından antropolojik açıdan çalışılmıştır. Yapılan çalışmalarda tiyatro içinde kilise çevresiyle, cavea (oturma basamakları) ve tiyatro dışında olarak iki grup halinde çıkarılmış olup Geç Bizans Dönemine tarihlendirilmiştir. Ayrıca iskelet buluntuları cavea dışı ve içi olarak ayrılmış olup, erkek ve kadın sayısının eşit olmadığ görülmüştür. Cavea içinde ele geçen iskelet kalıntıları, savaş sırasında ölen erkeklere ait olduğu düşünülmektedir. (Erdal, 1993:243-245)

\section{BULGULAR}

2012-2015 yıllarındaki kazı çalışmalarında tiyatronun güney kesiminde ele geçen 30 iskeletin dişleri üzerinde çalışılmıştır. Bu çalışmada öncelikle cinsiyet belirlenmesi için cranium ve pelvis kemikleri incelenmiştir. (Meindl ve Lovejoy; 1985; Buikstra ve Ubelekar; 1994; Scheur; 2002) Yaş için kaburgaların sternal uçları, symphysis pubis, ilium, diş sürmeleri ve kafatası süturlarının kapanış izlerine bakılmıştır. (İşcan-Loth ;1986; Buikstra ve Ubelekar; 1994 Todd; 1920; Brooks ve Suchey ;1990; Meindl ve Lovejoy ;1985)(Tablo:1 bkz.) 113 daimi diş 15 süt dişi olmak üzere toplam 128 diş diş çürügü, diş aşınması, diş taş1, apse, antemortem diş kayb1, ve hypoplasia yönünden incelenmiştir. 
Tablo 1: Bireylerin Yaş ve Cinsiyete Göre Dağılımı

\begin{tabular}{|l|l|l|}
\multicolumn{2}{c}{ Birey Sayıs1 } & 36 Haftalık \\
\hline Fetüs & 1 & $1,5-2$ \\
\hline Bebek & 3 & $8-10$ \\
\hline Çocuk & 2 & $35-50$ \\
\hline Erişkin & 3 & $18-24$ \\
\hline Genç & 3 & $26-50$ \\
\hline Kadın & 8 & $28-50$ \\
\hline Erkek & 5 & Erişkin \\
\hline Cinsiyeti Belirlenemeyen & 4 & \\
\hline
\end{tabular}

Diş çürükleri patolojik olarak en sık rastlanılan özellikle eski insan toplumlarında karşımıza çıkan ve en geniş araştırma konusu olan hastalıklardan birisidir. (Erkman, 2008:14) Çürük mikro-organizmalar ile başlar ve organik enzimlerin tahribatı şeklinde devam eder. ( Sözer, Erol, 2017:15; Yaşar, 2007:14) Diş çürükleri beslenme örüntüleri ve besin çeşitleri ile sıkı bir ilişki içerisindedir. Ayrıca diş çürüğü oluşumunda hijyen, yap1, genetik özellikler , sosyo-kültürel açıdan birçok neden gösterilebilir.(Sözer, Erol 2017:15) Bizanslıların dişlerinde çürüme oran1, günümüzdeki özellikle gelişmiş ülkelerle karşılaştırıldığında daha düşüktür. (Özbek, 1984:85)

$\mathrm{Bu}$ çalışmada 30 kişiye ait alt ve üst çeneye ait 128 diş incelendiğinde çürüme oran1 \%25'dir. Diş çürüğü bizlere besin örüntüleriyle ilgili bilgi verebilmektedir. Karbonhidratlı yiyecekleri de tükettiklerini söyleyebiliriz. Çürükler aşınmaya da bağlı, sert kabuklu yiyecek ve üçüncü iş kolu olarak kullanılmasından kaynaklanmaktadır. (Resim 1 ve Resim 2 bkz.) 


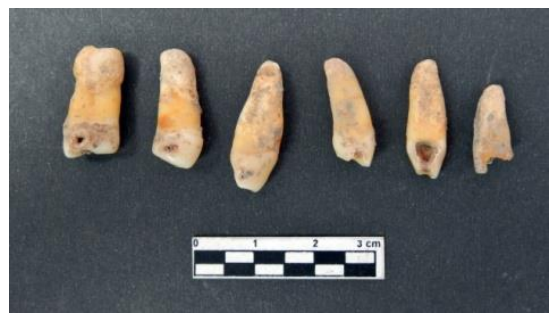

Resim 1:Çürükler

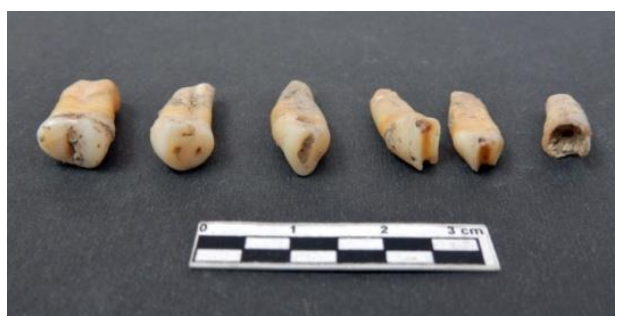

Resim 2:Aşınmaya bağlı çürük

Diş sorunlarından biri olan apse enfeksiyon sonucu oluşmaktadır. Diş çürüğü, periyodontal enfeksiyonlar, travma sorunlarından oluşan bir hastalıktır. Alveollerin iltihaplanarak, kök içindeki dokuları çevrelemesi ve dişten kemiğe yayılım göstermesi apseye neden olmaktadır. (Özbek, 2007:63) Apsenin, geçmiş toplumlarda oluşmasının nedenleri sağlik, beslenme, travmadan kaynaklanan aşınma ve çürüklerden kaynaklanmaktadır. (Sözer, Erol, 2017:28) Bu çalışmada 128 diş incelendiğinde \%7.8 oranında apse görülmektedir. Bu çalışma apsenin görülme sıklığının az olması beslenme, sağlık, travma açısından kötü olmadığını gösterebilir fakat apsenin postmortemden kaynaklı görülemeyeceğini de göz önünde bulundurmak gerekir.(Resim:3, Resim: 4 bkz.)

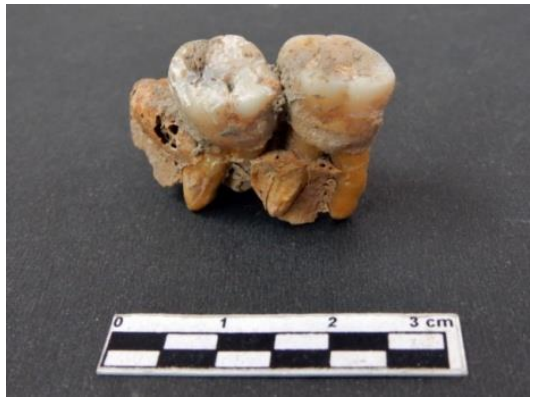

Resim 3: Apse

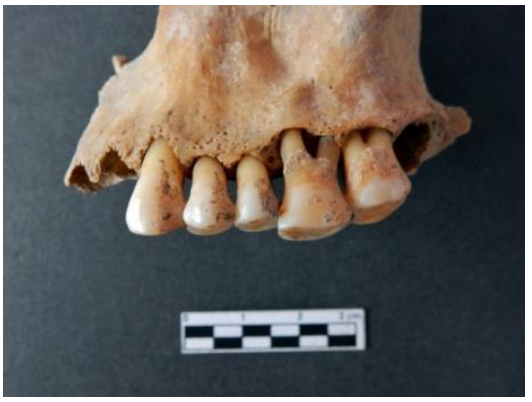

Resim 4: Apse

Hypoplasia; yetersiz ve kötü beslenme, çeşitli enfeksiyonlar, bulaşıc1 hastalıklar, travma, stres gibi sorunlardan meydana gelen ve diş tacında oluşan tranvers çizgi veya çukurluklardır.(Sözer- Erol 2017:27; Erkman 2008: 49) Süt dişlerinden daimi dişlere kadar görülebilmektedir. Hypoplasia 
anne karnında yetersiz beslenmeden kaynaklanabilir. 128 dişte hypoplasia \%25.7 oranında görülmüştür. Köpek dişlerinde daha yoğun görülmüştür. 2 ve 3 bantlı (çizgili) görülmüştür. Ayrıca tranvers çizgili hypoplasia dışında 2 bireyde çukur şeklinde hypoplasia mevcuttur. Stres, yetersiz beslenme ve sağlık sorunlarının etkisiyle yaşadıkları dönemde bulaşıcı hastalık, savaş gibi sorunların olduğu ve bu yüzden ileri derecelerde görünmesi mümkündür. (Resim:4 bkz) Bizans toplumunda, sağlık durumlarının göstergesi olan paleopatolojik bulgular da, cavea içi ve dışı gruplan arasında farkl1lıklar göstermektedir. İznik topluluğunda, başta travmalar olmak üzere birçok patolojik oluşuma rastlanılmış. Cavea içi ve cavea dışı gömülere bakıldığında ise cavea içi askerlere cavea dışı halka ait olduğu anlaşılmıştır.(Erdal 1993:246)

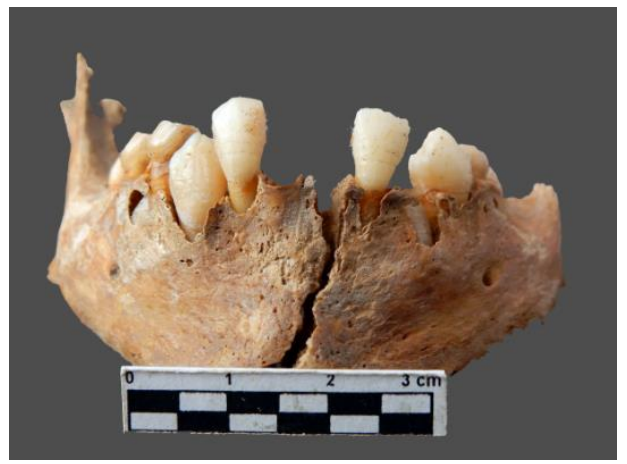

Resim 4: Hypoplasia

Besinlerin çiğnenmesiyle dişlerde oluşan tahribattır. Diş aşınmaları besinlerin sertliği, yiyeceklerin yenme şeklini, kültürel ve üçüncü bir iş kolu ile ilgili aşınmalar hakkında da bilgiler vermektedir. Aşınma, kabuklu gıdalar gibi yüzeylere zarar veren aşındırıcı parçacıklar nedeniyle sürtünme ve çiğneme gibi fizyolojik oluşan bir durumdur. Diş aşınması abrazyon, atrisyon ve erozyon olmak üzere üçe ayrilmaktadır. (Lukacs 1989:2) Abrazyon dişlerin fizyolojik olmayan, mekanik sürtünme ile aşınmasıyla oluşan ve üçüncü bir el gibi iş kolu kullanımında etkindir.( Erkman 2008:31, Sözer- Erol 2017:26) Asidik maddelerin yüksek olduğu besinlerin tüketilmesi ile oluşan diş aşınmasına erozyon denir. Atrisyon ise dişlerin birbirine sürtünmesiyle oluşan mekanik aşınmadır. (Lukacs 1989:2) Bu çalışmada aşınma 128 dişte \%27.3 oranında görülmüştür. Bireylerin bir kısmında yoğun aşınma görülürken diğer bir kısmında daha az aşınma görülmektedir. Aşınmanın yoğun olduğu dişler daha kabuklu, sert besinlerle 
beslendiğini gösterirken hafif aşınma görülen bireylerin yumuşak besinlerle beslendiğini göstermektedir. Bu çalışmada dişler üçüncü bir iş kol kullanımına dayalı aşınmalar mevcuttur. Mesleki olarak deri işleri, ip eğirme veya ağ yapımı gibi işlemler yapmış olabileceğini göstermektedir. (Resim:5, Resim:6 bkz.)

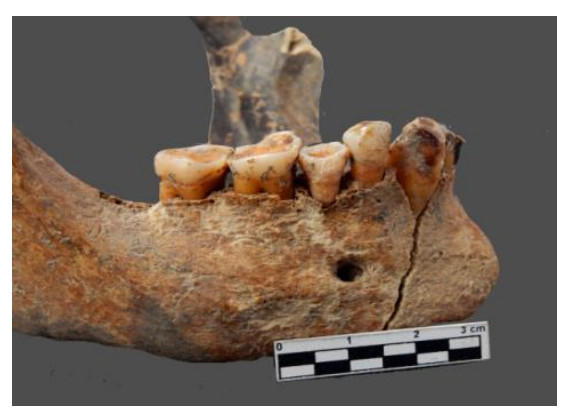

Resim 5

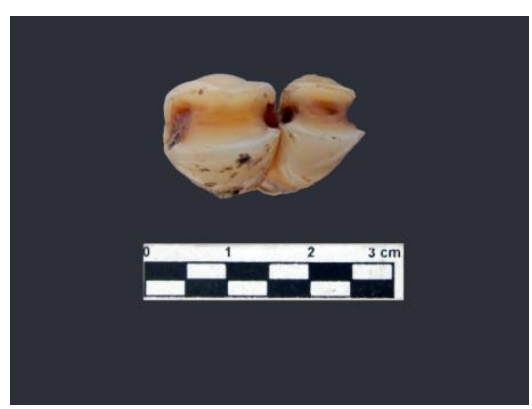

Resim 6 (İşten kaynaklı aşınma)

Diş taş1, bir plak oluşumudur. Tükürük plak oluşumunda rol oynar. Karbonhidrat ve proteinle beslenen bireyde daha fazla ve sıklıkla tükürük bezine yakın olan dişlerin yüzeylerinde görülür.(Sözer, Sevim, 2017:29, Erkman, 2008:50) Diş taşları besinlerin diş yüzeyinde birikerek sert bir hal almasıdır. Ayrıca dişlerde kahverengi ve siyah renkte oluşmaktadır. Diş taşı her toplulukta görülmesine rağmen toplumdan topluma değişebilmektedir.(Özbek, 2007:55) Bazı bireylerde dişleri tamamen kaplarken bazılarında hafif bazılarında görülmemektedir. Bu çalışmada 128 dişte \%15.6'nda diş taşı görülmüştür. Diş taşının fazla görüldüğü bireylerin protein ve mineral açısından zengin beslendiğini söyleyebiliriz. (Resim:7 bkz.)

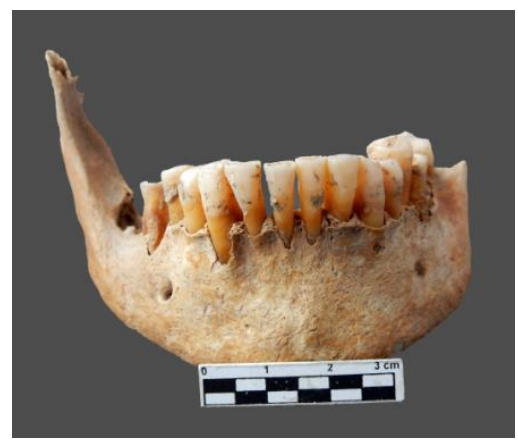

Resim 7: Diş Taş1 
Antemortem ilerlemiş çürük, belirgin aşınma, travma veya periodontal hastalık sonucu ölüm öncesi diş kaybıdır.(Özbek, 2007:66-67) Diş çekimi sıklıkla kullanılan bir yöntem olduğundan geçmiş insan topluluklarında karşılaşılmaktadır. Antemortem diş kayıpları daha çok premolar ve molar dişlerde görülmektedir (Yaşar, 2007:37) Bu çalışmada 128 dişin \%15.6's1 ölmeden önce dişlerini kaybetmiştir. (Resim 8 bkz.) Dişlerini çürük, şiddetli aşınma gibi birçok sorundan kaybettiğini göstermektedir. İncelenen dişlerde daha çok molar dişler antemortemdir. Bunun sebebi molar dişlerin fazla aşınmasıdir.

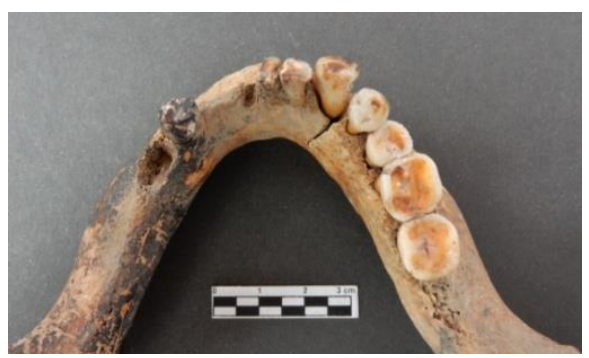

Resim 8: Antemortem

\section{SONUÇ}

İskeletler, kazı çalışmalarında seramik gibi arkeolojik buluntular yardımıyla Geç Bizans dönemine tarihlendirilmiştir. Daha önceki y1llara ait kazılarda iskelet kalıntıları tiyatronun içinde cavealarda, toplu gömüler şeklinde bulunmuştur. Bu gömüler çoğunlukla erkek birey ve savaşırken ölen askerlere ait olabileceği düşünülmektedir. (Özbek, 1984:89) Önceki çalışmalarda cavea içinden çıkarılan iskelet kalıntılarının aksine 2012-2015 yılları arasında yapilan kazı çalışmasında tiyatronun güneyinde yer alan mezarlık alanından çıkarılmıştır. Dişler geçmiş topluluklar hakkında önemli veri sağlamaktadır. Bu çalışmada dişler üzerinden; yaş, beslenme, sağlık ve üçüncü bir iş kolu olan izler gözlemlenmiştir. Toplum genelinde incelenen dişlerde gözlenen aşınma izlerinin oluşmasında sert, iri, lifli besinlerin hazırlanması ve iş gücü için kullanımının etkin olduğu, beslenme alışkanlıkları açısından karbonhidrattan daha çok tarımsal ve protein ağırlıklı besinlerle beslenildiği düşünülmektedir. İznik gölü olan bir yerleşim alanıdır. Konumu gereği tarımsal ürünler, proteinli besinlerin yanı sıra su ürünleriyle de beslenildiği 
düşünülmektedir. Kazı alanından çıkan midye ve hayvan kalıntıları ile desteklenmektedir. Böylece toplumların beslenme alışkınlıkları çevre ve iklim koşullarına göre de şekillenmektedir.

\section{KAYNAKÇA}

AYDIN, S. ve Kudret, E. (2009), Antropoloji Sözlüğü Bilim Sanat Yayınları, Ankara.

ERKMAN, A., C. (2008), Van Dilkaya Erken Demir Çağı ve Orta Çă̆ Toplumunda Ağız ve Diş Sağliğ Doktora Tezi, Ankara.

EROĞLU, S. (2009), "Ölçülemeyen Diş Özelliklerinin Biyolojik Uzaklık Çalışmaları" Mustafa Kemal Üniversitesi Sosyal Bilimler Enstitüsü Dergisi, Sayı:11, 545-570.

LUKACS J.R. (1989), Dental paleopathology: Methods for reconstructing dietary patterns. M.Y.Iscan and K.A.R.Kennedy (Eds). Reconstructing of Life from the Skeleton. Alan Liss, New York.

MERİ̧, A. (2017), "İznik Roma Tiyatrosu Kazılarında Son Durum", Bursa'da Zaman Dergisi, Say1:24, 8-11.

ÖZBEK, M. (1997), "Çayönü Tarım Toplumunda Diş Sağlığı", Türk Arkeoloji Dergisi, Say1:16, 181-216.

ÖZBEK, M. (2007), Dişlerle Zamanda Yolculuk, Hacettepe Üniversitesi Yayınları, Ankara.

ÖZBEK, M. (1984), "Roma Açık Hava Tiyatrosundan (İznik) Çıkarılan Bizans İskeletleri”, Hacettepe Üniversitesi Edebiyat Fakültesi Dergisi, Sayı:2 1, 81-89.

SÖNMEZ SÖZER, Ç. - Sevim Erol, A. (2017), "Antik Toplumlarda Görülen Diş ve Çene Patolojilerinin Antropolojideki Önemi” MASROP E-Dergi 24-37.

YAŞAR, Z. F. (2007), Adli Dental Antropoloji: Dental Antropoloji Açısından Minnetpınar ve Güllüdere Toplumlarının Dişlerinin Karşılaştırmalı Analizi Doktora Tezi Ankara.

YILMAZ, S. E. (1992), İznik Geç Bizans Topluluğunun Demografık Analizi VIII. Arkeometri Sonuçları Toplantısı 25-29 Mayıs, 243- 259. 
